\title{
ДИСкУССИИ
}

DOI: https://doi.org/10.15688/jvolsu2.2018.4.20

UDC 81'27:711.42

Submitted: 17.09.2018

LBC 81.006 .2

Accepted: 15.10 .2018

\section{THE ALL-SEEING EYE OF THE CITY FROM THE PERSPECTIVE OF URBAN COMMUNICATION STUDIES ${ }^{1}$}

\author{
Olga A. Leontovich \\ Volgograd State Socio-Pedagogical University, Volgograd, Russia; \\ Tianjin Foreign Studies University, Tianjin, China
}

\begin{abstract}
The research is carried out from the perspective of urban communication studies and uses the analytical sociolinguistic framework, which provides an opportunity to reveal the role of different semiotic signs in creating the image of a big city as an existential space. The paper focuses on surveillance as a common communication practice and investigates the system of Russian semiotic signs surrounding a city dweller as an object of surveillance. Signs construct the communicative situation of surveillance, which includes a subject, object, place, time, aim of surveillance and the consequences of actions seen as forbidden or undesirable. An important place in the study belongs to the notion of social visibility, which acquires a new meaning in the context of the research. The subjects of surveillance are unidentified representatives of power, whereas its objects are common citizens. Semiotic signs reflect the asymmetry of the social relationship between them (the subject of surveillance is invisible, the object is visible; the state demonstrates the paternalistic attitude towards its citizens). The modality of the message reflects the type of relationship between the subject and the object of surveillance and its social dynamics. The findings indicate that semiotic signs connected with surveillance become a powerful means of social stratification and regulate social relations in Russian urban discourse.
\end{abstract}

Key words: urban communication, sociolinguistics, semiotics, social visibility, surveillance studies.

Citation. Leontovich O.A. The All-Seeing Eye of the City from the Perspective of Urban Communication Studies. Vestnik Volgogradskogo gosudarstvennogo universiteta. Seriya 2, Yazykoznanie [Science Journal of Volgograd State University. Linguistics], 2018, vol. 17, no. 4, pp. 206-213. DOI: https://doi.org/10.15688/ jvolsu2.2018.4.20

УДК 81 '27:711.42

Дата поступления статьи: 17.09.2018

ББК 81.006 .2

Дата принятия статьи: 15.10 .2018

\section{ВСЕВИДЯЩЕЕ ОКО ГОРОДА С ПОЗИЦИЙ МЕДИАУРБАНИСТИКИ ${ }^{1}$}

\section{Ольга Аркадьевна Леонтович}

Волгоградский государственный социально-педагогический университет, г. Волгоград, Россия Тяньцзиньский университет иностранных языков, г. Тяньцзинь, Китай

Аннотация. Статья посвящена рассмотрению роли семиотических знаков в создании облика города как экзистенциального пространства. Исследование проведено с позиций социолингвистического направления, выделяемого в рамках медиаурбанистики. В его задачи входит: 1) анализ системы семиотических знаков, окружающих современных городских жителей, как объектов наблюдения, которое осуществляется с помощью видеокамер и иных средств; 2) обоснование их лингвопрагматической значимости для фиксации и 
трасляции актуальных урбанистических смыслов, с помощью которых реализуется задача социального контроля в современных городах. Показано, как семиотические знаки конструируют коммуникативную ситуацию наблюдения, включающую его субъект, объект, время, место, цель и последствия действий, нарушающих общественные нормы. Значительное место в работе отводится анализу феномена социальной видимости человека, который в контексте данного исследования обретает новый смысл. Раскрывается суть асимметричных отношений между субъектом наблюдения (как правило, представителем власти) и объектом (рядовым гражданином), выделяются отражающие их семиотические знаки. Предлагаются приемы выделения вербализуемых смыслов с позиций медиаурбанистики; рассматривается феномен модальности транслируемого знаками урабанистики смысла. С опорой на положение, согласно которому модальность вербального сообщения зависит от характера и сферы коммуникации, показано, что семиотические знаки, связанные с наблюдением как коммуникативной практикой, являются эффективным средством социальной стратификации и регулирования общественных отношений.

Ключевые слова: медиаурбанистика, социолингвистика, семиотика, социальная видимость, тотальное наблюдение.

Цитирование. Леонтович О. А. Всевидящее око города с позиций медиаурбанистики // Вестник Волгоградского государственного университета. Серия 2, Языкознание. - 2018. - Т. 17, № 4. - С. 206-213. - DOI: https://doi.org/10.15688/jvolsu2.2018.4.20

\section{Introduction}

This research is done in the context of urban studies - a rapidly developing area, which brings together specialists from different fields: architects, city planners, sociologists, political scientists, specialists in communication studies, etc. The sociolinguistic approach, which forms the analytical framework of this paper, provides an opportunity to reveal the role of different semiotic signs in creating the image of a big city as an existential space. The paper has an overall focus on surveillance as a common communication practice and investigates the system of semiotic signs surrounding a city dweller as an object of surveillance.

\section{Rationale for the study}

In urban communication studies a city is interpreted as: 1) a communication system of its own combining different channels, forms and means of human interaction; 2) a discursive formation ("text" in a broad sense of the term); 3) a personal and collective identity marker; 4) context of communication; 5) a complex set of symbolic, material and technological media; 6) a source of social and cultural development [e. g. see Aiello, Tosoni, 2016; Urban communication, 2007; Ridell, Zeller, 2013; etc.].

We view communication as a mode of human existence. One of the great challenges is to investigate how urban discourse reflects the dynamic processes unfolding in society. Our research brings together the theoretical frameworks of symbolic interactionism and critical discourse analysis. The latter stems from the works of M. Foucault [Foucault, 1977] who "sought to uncover the representational properties of discourse as a vehicle for the exercise of power" [Bryman, 2008, p. 508]. N. Fairclough [Fairclough, 2003, p. 37] interprets discourse as a kind of intermediate formation, which is situated at the intersection of the text per se and social context [Fairclough, 2003, p. 37]. He argues that discourses do not only reproduce the world as it is or as we are seeing it - they are also projective and may represent probable worlds, which the speakers would like to create [Fairclough, 2003, p. 124]. It means that discourses are capable of constructing the communicators' social worlds.

The adherents of critical discourse analysis [e. g. Blommaert, 2005, p. 25] believe that scholars should not only describe social aspects of language, but also provide moral and political critique of communication and use the research as a means of social impact.

Two different approaches, which can be traced in urban communication studies, are represented by the scholars who focus on 'media' - "ranging from cinematic or televisual representations to social networking and mobile communication - and those whose concerns lie mainly in the relationship between people and the urban built environment or in how different communities interact in urban contexts" [Aiello, Tosoni, 2016, p. 1255]. Our research is mainly centred on the second approach. 
We also employ the ethnographic method a set of methodological and interpretative techniques, which presupposes the scholars' immersion in the social life they are investigating. In the present study it is used to conceptualize different communication practices (technological, discursive, interactional) and includes combined reflective procedures related to urban social processes.

The research material includes verbal and nonverbal outdoor and indoor signs collected by means of ad libitum sampling from the Russian urban landscape, mainly in the city of Volgograd. The semiotic method is used to identify the subject and object of semiosis (who created the sign? whose worldview does it represent? who is the addressee? how is its perceived by different individuals and social groups?), investigate the signifier and the signified and reveal the factors of the sign's contextualization (to which extent do time and location determine the perception of the sign? how can the change of context influence its interpretation?).

\section{Social visibility}

In today's world, the city anonymity - the ability to get lost in a crowd - disappears or acquires new forms. The notion of "social visibility" has become one of the cutting-edge concepts in the works of Western scholars who approach it from different perspectives.

One of the opinions is that dominant social groups (e. g. white heterosexual middle-class men of medium age in the USA) are "invisible", since they constitute "the norm". Accordingly, the visible groups are those, which are a deviation from the norm and objects of discrimination: representative of non-white races, women, old people, children, sexual minorities, poor and homeless people, etc. From the linguistic point of view, their visibility is marked by a verbal indication of particular aspects of their identity, e. g.: Black student, female driver, нерусский (non-Russian), whereas groups seen as "the norm" do not call for such an identification.

According to another approach, discriminated groups, on the contrary, are regarded as invisible because they lack power and have no influence on social life [Anderson, Boyd-Franklin, 2000; Brooks, Gelderen, 2008; Scotland-Stewart, 2007].
People can be also described as visible if their communicative behaviour violates the existing rules or if their presence is inappropriate in a particular context (e. g. an older person at a teenage party, a foreigner in a local crowd, a drunkard in an elite restaurant, etc.).

Visibility as aggressive self-presentation is widely used in marketing when employees dress as Santa Clauses or cartoon characters to promote a new product or attract new clients.

Nowadays, due to the rapid development of new technologies, the notion of social visibility acquires a new meaning related to surveillance as part and parcel of contemporary urban life.

\section{Surveillance as a communication practice}

From the perspective of communication studies, surveillance denotes a binary relationship between subjects and objects of observation. It can refer to a wide range of phenomena: "faceto-face supervision, camera monitoring, TV watching, paparazzi stalking, GPS tailing, cardiac telemonitoring, the tracking of commercial / internet transactions, the tracing of tagged plants and animals, etc." [Walby, 2002, p. 158. Qtd. from Green, Zurawski, 2015, p. 29]. It is not limited to the study of its participants, but also takes into account a broader social context.

Surveillance studies are represented by the works of scholars who research it in the historical perspective [Genosko, Thompson, 2006; 2009], from the political point of view as an instrument of power [Fijnaut, Marx, 1995; Goold, 2004], as a violation of privacy [Lyon, Bennett, 2008; Rule, Greenleaf, 2008], etc. This theme attracts specialists in information technologies, legal studies, psychology, criminal studies, medicine, sociology, philosophy, anthropology, political studies, communication studies and sociolinguistics. Research shows that "human experience is now more visual and visualized than ever before" [Mirzoeff, 1999, p. 1].

Identity-based surveillance is a social phenomenon, a sign of our time; it takes into account people's race, ethnicity, age, gender, profession and social status. A person is an object of surveillance since the moment $\mathrm{s} / \mathrm{he}$ is detected as foetus; as a baby observed by parents, grandparents and nannies; as a teenager and adult for the sake of security and social control; "it 
continues to increase with passing years, intensifying and reaching its peak if an individual somehow starts to show any different behaviour or to deviate from the norms, thus immediately falling into the category of the "other'" [Mehrabov, 2015, p. 120]. Surveillance is done in the streets and squares, residential areas (yards, lobbies, lifts), shops, cafes, restaurants, on entertainment grounds and at work. It is maintained to control people's local, national and global mobility - in public transport, airports, on highways and at railways stations. Modern gadgets are capable of tracking our movements, even when we are walking.

Though in the process of surveillance a person demonstrates one's individuality, "through being observed, monitored and controlled", human bodies can also demonstrate collective identities [Jones, 2005, p. 592]. Surveillance studies allow scholars to analyse social stratification, behaviour, life in communities, etc.

Studies indicate that surveillance affects human relationships and causes ethical problems. It violates the maxim of quality of communication: mistrust prevails over sincerity. The paradox is that "the quest for privacy produces surveillance, because privacy is also looked to as protection against surveillance" [Lyon, 2002, p. 2].

I. Mehrabov points out that modern housing projects transform domestic spaces into self-prisons, which are, on the one hand, closely connected with the outside world with the help of information-communication equipment, and, on the other, separated from 'real' life with safety and surveillance technologies [Mehrabov, 2015, p. 121].

\section{Semiotics of surveillance in the context of Russian urban communication}

Surveillance as a communicative practice is accompanied by the use of numerous semiotic signs, which have become an integral part of the modern urban landscape. Semiotic signs do not only designate the presence of video cameras and other surveillance means - they serve to construct corresponding communicative situations, within the framework of which we can single out a subject, object, place, time, aim of surveillance and consequences of actions seen as prohibited or undesirable.
Verbal, nonverbal and mixed signs are omnipresent in a city landscape. First of all, these are signs indicating the fact of surveillance per se. The most widely spread are those with the image of a CCTV camera or the message: Bнuмание! Ведется видеонаблюдение (Attention! Video surveillance / You are being watched). If in some countries (e. g. the UK) the law prescribes to have a sign indicating the presence of the camera nearby, in Russia this is not a necessary legal requirement. Therefore, such inscriptions as: Объект оборудован скрытыми видеокамерами. Вас снимает скрытая видеокамера! (The premise is equipped with hidden video cameras. You are being watched by a hidden video camera) cannot be regarded as an infringement of the civil rights. Such signs are installed not to meet the legal requirements, but rather to achieve the aims of surveillance itself - informing, warning, intimidating.

Subject and object of surveillance. The processes of surveillance are connected with the use of particular semiotic signs pointing to different types of relationship between the addresser and the addressee of the message. Being a binary process, surveillance implies the presence of the subject and object - the one who is watching and who is being watched. This is a power relationship: the subjects are usually representatives of the state or institutions possessing authority, and the objects are common citizens.

The analysis of the Russian semiotic signs shows that, as a rule, the subject of surveillance is unidentifiable. Russian grammar provides numerous resources allowing to hide the subject of surveillance, e. g.: Ведется видеонаблюдение (Surveillance is being carried out); $У_{c-}$ тановлены скрытые видеокамеры (Hidden videocameras are installed); Bac снимает скрытая камера (You are being watched by a hidden videocamera); Объект под охраной (The premise is under surveillance); Объект оборудован скрытыми видеокамерами (The premise is equipped with hidden videocameras).

The participants of the conference "City Talk: Urban Identities, Mobilities and Textualities" (Bern, Switzerland, Dec. 11 - 12, 2017) paid attention to the fact that in practically all the pictures demonstrated by R. N. Jones in his brilliant presentation "The City is Watching you" 
video cameras are looking down (demonstration of the powerful position). In the same presentation, the author pointed out that semiotic signs often use the eye as a symbol: citizen are watched by the all-seeing eye of the state ("Big Brother"). The eye is also widely used in Russian signs, alongside with the inscriptions: Я слежу за тобой (I am watching you); Большой брат следит за тобой (Big Brother is watching you).

The relationship between the subject and the object of surveillance is marked by communicative asymmetry: the subject is invisible, whereas the objects are visible to a camera or a security guard. Even if the inscription is used selectively, e. g. Bоры будут наказаны (Thieves will be punished), citizens knowing that they are not thieves feel a certain degree of discomfort (are they suspected as potential thieves?). Besides, let us pay attention to the impolite $t y$-address (second person singular): Я слежу за тобой (I am watching yоu); Большой брат следит за тобой (Big Brother is watching you). Another manifestation of asymmetry is the fact that next to the inscription: Внимание! Ведется видеонаблюдение (Attention! Video surveillance) there is often a sign: Фото- и видеосъемка запрещены (The use of photo and video cameras is not allowed), which means that one side can watch the other, but not vice versa.

Examples of other inscriptions connected with the display of power are: В иелях улучшения обслуживания все разговоры записываются (To improve the quality of service, all the conversations are audio recorded); Видеонаблюдение ведется в иелях вашей безоnасности (Video surveillance is done for the sake of your security). They demonstrate the paternalistic attitude towards citizens implying that they are being watched like children, for their own benefit.

Signs may also act as effective means of dividing people into ingroups and outgroups, "us" and "them", if their action is selective: Посторонним вход воспрещен! (Strangers are not allowed!); Вход без спецодежды запрещен (Entrance without a working uniform is prohibited); Проход запрещен. Частная терpuтория (No trespassing. Private territory).

At the same time, in spite of the presence of a sign, a person can never be sure that he or she is really watched - whether there is a real or dummy video camera, a hidden camera or no camera whatsoever.

Time and place of surveillance. In a number of cases the sign specifies the area which is being watched: B помещении / в магазине / на территории / в лифте / в подъезде / в храме ведется видеонаблюдение (The premise I shop / lift / cathedral is under surveillance).

Sometimes it indicates the time of surveillance: Объект находится под наблюдением 24 часа / Ведется круглосуточное видеонаблюдение (The premise is under surveillance 24 hours as day).

Aim of surveillance. Surveillance is usually maintained to prevent asocial, undesirable actions, such as smoking, drinking alcohol, theft, walking dogs in wrong places, etc. Accompanying signs may verbally explain the prohibition: Запрешается принимать пищу (Eating is not allowed); Kyпаться запрещено (No swimming); C пивом вход воспрещен! (Entrance with beer is prohibited!); Пожалуйста, не прикасайтесь $\kappa$ двери! (Please do not touch the door!); Въезд на территорию парка на велосипеде запрещен (Bicycles on the territory of the park are not allowed).

Nonverbal signs are becoming more and more popular - crossed out images of a cigarette, a burning match, a bottle, a glass, ice-cream, camera, cell phone, dog, motorcycle, etc. They are often used in places frequented by tourists because they can be understood by speakers of different languages. Mixed signs which carry both an image and an inscription are also widely used.

There are reasons to assume that the probability and acceptability of certain types of communicative behaviour is culturally conditioned. E. g. the Russian traffic rules allow drivers to use the car horn only to avoid accidents or to warn other drivers about overtaking; the violators of this rule are subjected to fines. In India, on the contrary, drivers use the horn all the time, and some trucks even carry the inscription: Please horn.

Content of verbal messages. The content of the message is directly related to the addressee's (in)visibility. The signs may be classified as inviting: Ведется видеонаблюдение. Рады вас видеть! (Video surveillance. Glad to see you!), filtering: Посторонним вход запрещен (No strangers allowed), and prohibiting: По газонам не ходить (No 
walking on the lawns). The sign Добро пожаловать! (Welcome!) above the door of an airport business lounge does not mean that everybody is really welcome - it is possible to speak about different kinds of visibility: a well-dressed confident client is visible for the staff but does not arouse suspicions, unlike those who do not fit into the social context. The latter will be approached by the attending personnel who would want to check their right to spend time in the business lounge. The appearance, clothes, communicative behaviour (conforming to or contradicting the norms of a particular social group) are also powerful semiotic signs.

Surface and in-depth meaning of verbal messages. The asymmetry between the signifier and the signified in verbal messages related to surveillance results in the discrepancy between what is actually said and what is meant. As a rule, the simple message: Внимание! Ведется видеонаблюдение (Attention! Video surveillance) indicates that people must behave well. The inscriptions: Здесь не собачий туалет; Здесь гуляют дети! (This is not a toilet for dogs; Children at play!) mean the same thing as: Выгул собак запрещен (Walking of dogs prohibited). There are also messages with zero meaning, e. g. the absence of access ramps and elevators implies that people in wheelchairs are not welcome, which makes them socially invisible.

Modality of verbal messages. Modality reflects the type of social relationship between communicators. Peremptory wording means that the message is given from a position of strength: Вход посторонним строго запрещен! (Strictly no trespassing). In some cases, it is accompanied by an intimidating image (e. g. a scull with crossed bones) or a threat: Выгулл coбак запремен. Штраф 1000 руб. (No dog walking. Fine 1000 roubles); Mycop не бросать! Поймаем - вывезешь все! (No trash! If we catch you, you'll clean up everything!); Частная территория. Парковка без разрешения строго запрещена! Шины будут спускаться (Private territory. No parking without permit. Tires will be deflated).

Such inscriptions are typically present at private premises and are addressed to people with whom the owner is not planning to interact otherwise. Milder modality is typically used in the service sector, and its choice can be explained by the wish not to offend a potential client: Территория, свободная от курения и распития спиртных напитков (Territory free of smoking and alcohol); Зона, свободная от алкоголя (Alcohol-free zone); Hе copume, пожалуйста (Do not litter, please).

A more liberal, non-traditional form of expressing prohibition is embodied in creative phrases, such as: Просьба... не курить (Please... do not smoke), where the dots are used to denote a tactful pause.

Humorous phrases indicate an egalitarian, democratic relationship between the addresser and addressee: Ульббнитесь! Вас снимает скрытая камера (Smile! You're on hidden camera); Ведется видеонаблюдение, бездельники! (Video surveillance, lazybones!).

Mirrors can be used for marketing purposes to flatter the customer, e. g. the inscription on a mirror: Наш любимый клиент (Our favourite client).

Violators become socially visible. Undesirable actions can cause unpleasant consequences: an alarm will sound, a guard or a policeman will show up, a video camera will record the violation, a fine will be administered, etc.

The analysis shows that semiotic signs connected with surveillance have become a powerful means of social stratification and regulate social relations in Russian urban discourse.

\section{Results}

1. Surveillance is an indispensable element of the modern Russian urban landscape and is reflected in semiotic signs of different nature.

2. Signs construct the communicative situation of surveillance, which includes the subject, object, place, time, aim of surveillance, as well as the consequences of the actions seen as forbidden or undesirable.

3. As a rule, the subjects of surveillance are unidentified representatives of power, whereas its objects are common citizens. Semiotic signs reflect the asymmetry of the social relationship between them (the subject of surveillance is invisible and the object is visible; the state demonstrates its paternalistic attitude towards citizens).

4. The modality of the message reflects the type of relationship between the subject and the object of surveillance and its social dynamics. 


\section{Conclusion}

The understanding of the social processes happening in big cities requires an integrated study of modern media technologies and patterns of human communication. We seek to further extend our findings in order to shed light on the ethical and cultural consequences of surveillance in Russia, as well as to compare them to other cultures.

\section{NOTE}

${ }^{1}$ The reported study was funded by the Russian Foundation for Basic Research according to the research project No. 17-29-09114.

\section{REFERENCES}

Aiello G., Tosoni S., 2016. Going About the City: (Methods and Methodologies for Urban Communication Research. International Journal of Communication, no. 10, pp. 1252-1262.

Anderson F., Boyd-Franklin N., 2000. Invisibility Syndrome: A Clinical Model of the Effects of Racism on African-American Males. URL: https://www.bc.edu/content/dam/files/centers/ boisi/pdf/f08/Invisibility_Clinical_ModelOrtho-.pdf.

Blommaert J., 2005. Discourse. A Critical Introduction. Cambridge, Cambridge University Press. 314 p.

Brooks K., Gelderen T., 2008. Fighting invisibility: The recognition of migrant domestic workers in the Netherlands. URL: https://www. humanityinaction.org/knowledgebase/103fighting-invisibility-the-recognition-of-migrantdomestic-workers-in-the-netherlands.

Bryman A., 2008. Social Research Methods. Oxford, New York, Oxford University Press. 747 p.

Fairclough N., 2003. Analysing Discourse. New York, Routledge. $270 \mathrm{p}$.

Fijnaut C., Marx, G.T., 1995. Undercover: Police surveillance in comparative perspective. Norwell, Kluwer Academic Publishers. 343 p.

Foucault M., 1977. Discipline and Punish. Harmondsworth, Penguin. 333 p.
Genosko G., Thompson S., 2006. Administrative surveillance of alcohol consumption in Ontario, Canada: pre-electronic technologies of control. Surveillance \& Society, vol. 4, no. 1/2, pp. 1-28.

Genosko G., Thompson S., 2009. Punched drunk: alcohol surveillance and the LCBO 1927-1975. Nova Scotia, Fernwood Publishing. 222 p.

Goold B., 2004. CCTV and policing: Public area surveillance and police practices in Britain. Oxford, Oxford University Press. $260 \mathrm{p}$.

Green N., Zurawski N., 2015. Surveillance and Ethnography: Researching Surveillance as Everyday Life. Surveillance and Society, vol. 13, no. 1, pp. 27-43.

Jones H., 2005. Visible rights: Watching out for women. Surveillance \& Society, vol. 2, no. 4, pp. 589-593.

Lyon D., 2002. Editorial. Surveillance studies: understanding visibility, mobility and the phenetic fix. Surveillance \& Society, vol. 1, no. 1, pp. 1-7.

Lyon D., Bennett C., 2008. Playing the ID card: Understanding the significance of identity card systems. Lyon D., Bennett C., eds. Playing the identity card: surveillance, security and identification in global perspective. London, Routledge, pp. 3-20.

Mehrabov I., 2015. Exploring Terra Incognita: Mapping surveillance studies from the perspective of media and communication research. Surveillance and Society, vol. 13, no. 1, pp. 117-126.

Mirzoeff N., 1999. An Introduction to visual culture. London, Routledge. $288 \mathrm{p}$.

Ridell S., Zeller F., 2013. Mediated urbanism: Navigating an interdisciplinary terrain. International Communication Gazette, vol. 75, no. (5-6), pp. 437-451.

Rule J.B., Greenleaf G.W., 2008. Global privacy protection: the first generation. Cheltenham, Edward Elgar. 318 p.

Scotland-Stewart L., 2007. Social invisibility as social breakdown: Insights from a phenomenology of Self, World, and Other. Stanford, Stanford University. $235 \mathrm{p}$.

Gibson T.A., Lowes M. (eds.), 2007. Urban communication: Production, text, context. Lanham, MD, Rowman \& Littlefield. $241 \mathrm{p}$.

Walby K., 2002. Little England? The Rise of OpenStreet Closed Circuit Television. Surveillance \& Society, vol. 4, no. 1, pp. 29-51. 
O.A. Leontovich. The All-Seeing Eye of the City from the Perspective of Urban Communication Studies

\section{Information about the Author}

Olga A. Leontovich, Doctor of Sciences (Philology), Professor, Head of Department of Intercultural Communication and Translation, Volgograd State Socio-Pedagogical University, Prosp. Lenina, 27, 400066 Volgograd, Russia; Professor, Tianjin Foreign Studies University, Machang Road, 117, Hexi Disctrict, Tianjin, China, olgaleo@list.ru, https://orcid.org/0000-0002-0972-4609

\section{Информация об авторе}

Ольга Аркадьевна Леонтович, доктор филологических наук, профессор, заведующая кафедрой межкультурной коммуникации и перевода, Волгоградский государственный социальнопедагогический университет, просп. Ленина, 27, 400066 г. Волгоград, Россия; профессор, Тяньцзиньский университет иностранных языков, ул. Мачандао, 117, район Хэси, г. Тяньцзинь, Китай, olgaleo@list.ru, https://orcid.org/0000-0002-0972-4609 